\section{Rethinking privacy and publicity: Reading the spatial reflections of gender through Virginia Woolf's Mrs. Dalloway}

Begüm Sena ÖNAL ${ }^{1}$, ORCID: 0000-0002-7090-5062

Zeynep TUNA ULTAV², ORCID: 0000-0003-0478-7333

\begin{abstract}
This article deciphers socio-spatial characteristics of the London scene in the early twentieth century. Analyzing excerpts from Mrs. Dalloway (1925), a novel written by one of the prominent modernist and feminist writers, Virginia Woolf (1882-1941), the literary space analysis aims to ascertain how the narrative elucidates the relation between assigned gender roles and spatial practices of the protagonist Clarissa Dalloway. Revealing the abundance of socio-spatial information hidden in literary fiction, the three-partite spatial analysis that examines Mrs. Dalloway's living environment within the contexts of private (domestic) space, public space, and 'internal' space highlights new layers of textual meaning. Thus, the study exposes the spatial hints of Woolf that guide readers to understand the confined social position of a high society lady. Touching upon controversial issues that nurtured the private-public dichotomy, the study broadens the discussion of gendered space, discussing Woolfian space as a challenge to patriarchal codes. Excerpts examined throughout the article reveal that the author's critique on unequal power relations between men and women reveals itself in spatial portrayals in the novel. Therefore, scrutinizing Mrs. Dalloway allows rediscovering, reinvestigating, and rethinking privacy and publicity in the early twentieth century through modern fiction.
\end{abstract}

\section{Highlights}

- This article investigates the understanding of privacy and publicity and its representation in modern literature through spatial depictions.

- The study examines three physical spaces depicted in Mrs. Dalloway within the context of private space (the Dalloways' house), public space (the streets of London), and 'internal' space (the attic room).

- The literary analysis demonstrates the abundance of socio-spatial and socio-historical information hidden within modern fiction.

\section{Keywords}

feminist modernism; gender and space; literary space analysis; Mrs. Dalloway; Virginia Woolf

\section{Article Information}

Received:

17.04.2021

Received in Revised Form:

28.06.2021

Accepted:

26.07.2021

Available Online:

29.07.2021

\section{Article Category}

Research Article

\section{Contact}

1. Yaşar University, Interior Architecture and Environmental Design, Izmir, Turkey begum.onal@yasar.edu.tr

2. Yaşar University, Interior Architecture and Environmental Design, Izmir, Turkey zeynep.tunaultav@yasar.edu.tr 


\section{INTRODUCTION}

During the early twentieth century, social norms imposed by the male-dominated society has reinforced inequalities between men and women. As social positions of men and women were segregated in the context of spatial use as well -'public space for men' and 'private (domestic) space for women'- daily experiences and interactions of women have been much more limited compared to men. Virginia Woolf (1882-1941), one of the leading feminist and modernist writers of her era, was aware of these invisible patriarchal codes that restricted women's freedom regarding spatial experiences. Although not directly attacking the social system, Woolf portrayed to readers how these codes assigned and imprisoned women to standardized roles and spaces by means of her literary works. Albeit Woolfs protagonists do not seem to resist the status quo, the feminist stance she implemented in her literary work -e.g., Mrs. Dalloway (1925), Orlando: A Biography (1928), A Room of One's Own (1929)- has been accepted as a challenge to the unequal power relations between men and women.

Published on 14th May 1925, Mrs. Dalloway with London as its context is one of the most manifest examples of Virginia Woolf's interaction with a modern city as a feminist and modernist writer. Woolf portrays post-war London from the feminine perspective of the protagonist Clarissa Dalloway, and questions the fragility and destructibility of all restricted private/public norms that patriarchy offers as a 'favor' to women through Clarissa's spatial experiences. Unlike other modernist works, Woolf focuses on the private space rather than overlooking it. Despite the fact that the novel's narrative progresses mainly through the characters' journeys in the public sphere, Clarissa's private (domestic) space also often remains in view. Thus, the narrative allows readers to comprehend and contrast the opportunities and restrictions that public/private spheres of the city offer to the female protagonist. In this way, the author's point of view leads the reader to think about the new layers of spatial meaning (Uz Sönmez, 2007).

Mrs. Dalloway depicts a single day in 1922 of a high society lady, Clarissa Dalloway, who lives in Westminster district after World War I (Whitworth, 2005). On a mid-June morning, Mrs. Dalloway decides to visit Bond Street to buy flowers from the florist Mulberry's for her private party to be held at her house that evening. Leaving her home and taking a walk through the streets of London, Clarissa cannot stop herself from thinking about her reckless teenage years spent in Bourton's countryside. She first remembers her decision to marry the esteemed Richard Dalloway and become Mrs. Dalloway instead of being with Peter Walsh, who once yearned to marry her. Clarissa 
then recalls her impossible romantic relationship with a close female friend, Sally Seton. While she is shopping, Woolf shifts the narrative, introduces the male double of Clarissa, Septimus Warren Smith: namely the second protagonist of the novel. Septimus, who suffers from post-traumatic stress disorder as a World War I veteran, is a troubled character who still grapples with agonizing memories of the war, particularly with flashbacks about his close friend Evans, who died in the battle (Penner, 2000). On the same day, Septimus learns that he will be transferred to a mental institution and commits suicide by jumping out of a window, preferring to give up his life rather than seeing himself in such a condition.

Most of the characters written by Woolf in the novel, including those from Mrs. Dalloway's past, appear at Clarissa's party in the evening. When Clarissa hears of Septimus' suicide, whom she has never met before, she gets apprehensive that guests would talk about such tragic news at her party. Yet, she soon begins to reflect on Septimus' condition, and after isolating herself in an empty room, she deeply thinks how overwhelmed he must have felt. Gradually, Clarissa respects Septimus' decision to take his own life rather than endangering his self-esteem by allowing his soul to be imprisoned (Payne, 1978). In light of what Septimus had done to protect his soul, she contemplates circumstances in which she risked her own soul to live as 'Mrs. Dalloway'. This situation reflects the dichotomy between the choices of Clarissa and Septimus. Clarissa gives up her past life and romantic relationships to belong to the aristocracy: and chooses to be a high-society lady: although being a Dalloway means to be 'imprisoned' and lonely in the end. Septimus, on the other hand, prefers death to preserve the innocence and freedom of his soul. Therefore, he leaves behind the society that he no longer feels belonging to without a second thought. At first glance, the novel's themes are mainly based on the understanding of society and class, privacy, loneliness, and feminist criticism. Death and the traumatic effects of the interwar period on society are other themes of the novel, yet these are not considered in this article and remain open to further discussion.

Recent decades have witnessed a burgeoning interest in the spatial aspect of literary studies since space is one of the primary determinants of human experience; and offers a suitable paradigm to examine literary texts as world-building narratives. The concept of literary space proposed by Manfred Jahn is a representative spatial setting constructed from incomplete textual hints within the mind of the reader (cited in Bolak, 2000). Havik (2006), on the other hand, argues that literary spaces are often formed by the narrator's experiences, memories, and realities. The physical characteristics portrayed by narrators, such as the urban scene, buildings, streets, interiors, or decors, unavoidably reflect their persona and ideas. They become elements that shape their narratives and provide the time and space-related characteristics and social structure of the depicted society. Thus, by examining the narrator's spatial representations, the reader can trace historical information and reveal socio-spatial issues that hitherto remained either unresolved or unmentioned.

Another importance of spatiality in literature derives from the possibility of revealing the sociospatial conditions of men and women in a defined timeframe. Within this context, analyzing literary works is an essential method of spatial analysis because it can reveal the foundations of contemporarily debated gender and space-based issues. In parallel, fiction is one of the potential historical yet subjective sources that can be studied within the context of spatial analysis: as it presents socio-spatial cues about the period depicted from the narrator's point of view. 
Accordingly, the present study expressly tackles gender disparity and its reflections in spatiality using literary fiction as the source of decipherable socio-historical information.

Mrs. Dalloway is one of the contextually rich examples to trace the spatial cues of gender inequality during the early twentieth century's modern London scene. Although female characters are prominent in many British novels, Mrs. Dalloway diverges significantly from the others. Woolf's protagonist is a wealthy middle-aged woman; who has found a husband and taken her place in the institution of marriage, which marks her last 'free' action as a woman before being confined to the roles designated to her by society (Ergün, 1990). Therefore, readers often confront Clarissa's difficulty to cross the threshold of freedom throughout the narrative even though Woolf initially implies a feminist perspective in Mrs. Dalloway. While the protagonist is represented as a soul trapped between her past and the present, this congestion is exposed to readers through the plot that takes place between private and public gendered spaces.

Mrs. Dalloway's setting has been examined through various perspectives throughout the last five decades. The novel has especially received much attention from scholars who focus on the construction of identity and domestic space (e.g., Penner, 2000; Groover, 2008; Johnson, 2016) as well as the streets of London concerning experiences of the protagonist with the city (e.g., Squier, 1985; Wilson, 2001; Wood, 2003; Larsson, 2017). However, the impact of both private and public gendered spaces as producers of docile subjectivity in Mrs. Dalloway is a subject to be reviewed critically. Therefore, this article offers a three-partite analysis of spaces depicted in the novel to discuss the impact of spatiality as a material agency that forms the feminine subjectivity of Clarissa Dalloway. The comparative reading through three different spaces where the protagonist spends her quotidian life reveals the power of spatial descriptions for readers in making sense of the obedient identity of Mrs. Dalloway. The analytical approach investigates the understanding of privacy and publicity in Woolfian spaces while questioning the 'modern' foundations of the relationship between gender roles and spatial practices. Focusing on three spaces depicted: The Dalloways' house (private space), the streets of London (public space), and the attic room ('internal' space), the spatial analysis is used to explore how the multi-dimensional character of Clarissa is affected by the gendered spatial codes. In this regard, literary space analysis that focuses upon direct quotations from the novel becomes a convenient means to discover the private and public spaces that define early twentieth-century London within the living environment of the protagonist.

\section{WOOLF'S MODERNIST FICTION AND USE OF SPACE}

Utilizing the stream of consciousness as a narrative technique in literature, Virginia Woolf was a pioneering modernist writer of the twentieth century, a valued member of London's literary scene, and a representative of first-wave feminism during the interwar period. In this context, feminism was considered a set of constitutional, social, and cultural actions opposing male domination and gender disparity (Algweirien, 2017). Coming to the fore as one of the writers who noted "women's symbolic homelessness" (Baydar, 2012, p. 701), she sought to allow women's voices to rise through literature within the framework of feminist criticism. 
Woolfs attempt to deconstruct the repressive binaries she confronted in literature and generate a non-hierarchical literary discourse reveals itself in her narratives. The author's use of literature to question and challenge appointed gender roles from a feminist perspective runs parallel to the French feminist writer and literary critic Hélène Cixous' words: “Writing is precisely the very possibility of change, the space that can serve as a springboard for subversive thought, the precursory movement of a transformation of social and cultural structures" (1975, p. 879). Woolf's modernist viewpoint, on the other hand, was characterized in her literary work by a series of experiments that illustrated shifts in the experience of modern life. She attempted to trace new ways of understanding; in terms of the relationship between individuals' lives and space as constrained by society, especially regarding women's experiences in modern times.

Modernism evolved in the form of multiple visions and values that aimed to make men and women the subjects and objects of modernization, as the philosopher and Marxist writer Marshall Berman (1940-2013) points out in All That Is Solid Melts Into Air (1988). Modernity's initial phase approximately started in the early sixteenth century and lasted until the early eighteenth century. Considering the impacts of the Reformation and the Scientific Revolution (sixteenth and seventeenth centuries) as well as the Enlightenment (eighteenth century), the early stage of modernity has torn down the authority of the ecclesiastical institutions and enhanced the power of scientific achievements (Russell, 1945). During this time, societies began to explore modern life despite lacking a complete understanding of modernity since these new developments ran hitherto unquestioned conventional beliefs and values down. Therefore, this stage marks an era when both women and men tried to keep up with modern life, desperately looking for a suitable vocabulary while having no inkling of what a modern public meant as an environment for sharing their experiences, including social and spatial practices. As Berman (1988, p. 17) puts it, especially the daily life of the modern European public, which was on the verge of the most vehement revolutions, consisted of a social whirlwind, "le tourbillon social', in this period.

The second phase began with the revolutionary waves of the 1790s, including the effects of the French Revolution, when the modern public entered people's lives. This era also included economic, political, and social changes as a consequence of the development of scientific and technological innovations, urbanization, politics, and the emergence of nation-states. It was generally considered chaotic in personal, social, and political life since it has led to upheavals at both the social and individual levels. This phase expressed the transition from feudal social order to capitalist social order under the effects of industrialization, secularization, and rationalization (Habermas, 1990; Giddens, 1990; Barker, 2005). Therefore, it also brought new ideas, especially to the modern European public, including freedom for all people and the promotion of women's rights.

The third and final phase began in the twentieth century when modernization expanded worldwide. However, with this polycentric extension of the modern public, the understanding of modernism fragmented, causing a "lack of vividness, resonance, and depth" (Berman, 1988, p. 17). This fragmentation of subjective experience in space, time, and human relations also became the subject of literary analysis and affected ways of thinking in literature throughout the twentieth century. Virginia Woolf, for example, used the technique of stream of consciousness in most of her novels including Mrs. Dalloway to give the reader the impression that even the human self 'melts into the 
air' under conditions of modernity. With this technique, Woolf represented the reader with a mosaic portrait that collages Clarissa's and other characters' past and present together rather than chronicling the years of their life. Therefore, she conveyed the thoughts, feelings, emotions, and memories of the characters to the reader as they are.

In Mrs. Dalloway, Woolfs depiction of space regarding "multiplicity, seriality, and circulation" (Spurr, 2007, p. 479) adopts a unique structure in which a series of characters journey through the spaces of London (Spurr, 2012). Through these journeys, Woolf compares the social and cultural construction of private and public spaces: while the private (domestic) space is for women, public spaces are for men. These gendered public and private concepts originated in patriarchal societies' political, economic, and sexual norms. The notion of gendered space originates from the mode of thought that assigns a specific sphere to a particular gender within an exclusionary, patriarchal system that grants public space to male dominance while confining females to private space (the home). According to Rendell (2000, p. 103), this ideology that "divides the city from home, public from private, production from reproduction, and men from women is both patriarchal and capitalist". The traditional and gendered understanding of space in the early twentieth century debarred women from sharing men's spatial experiences while fostering male-dominated social authority. Spain (1992) indicates that the separation of public and private through spatiality has developed over centuries through social and cultural norms; these standardized gender roles have caused gender discrimination by giving men complete spatial access while minimizing women's. Therefore, the male-dominated realm that produces private (domestic) and public concepts exacerbated status disparity.

Architecturally speaking, women have been subjects who get spoken of by the patriarchal discourse that feminizes the subject and space, and portrays the subject as docile and easily malleable, especially in the domestic sphere (Baydar, 2005). Here, it is critical to consider the early twentiethcentury setting of Mrs. Dalloway, when the public sphere was mainly formed by Western Europe's bourgeoisie. In traditional bourgeoisie society, the sphere of women was limited to interior spaces (Smyth, 2008). With the impact of the feminist movements of the early twentieth century and the changing attitudes these movements brought, women sought to find their place in society rather than acknowledge their marriage-associated roles (Özcan, 2015). In this context, the Woolfian concept of space focuses on female figures who try to exist in public spaces besides private spaces: both materially and metaphorically. Woolf bases her feminist critique on private and public space, especially in terms of gender-based power relations. Therefore, Woolfian spaces encourage women's efforts to find their place in society by serving as a mechanism that questions unequal power relations. Mrs. Dalloway's uniqueness, at this point, stems from its consideration of the protagonist as an individual while putting her problems regarding sexuality forward.

\section{Woolfian Space: A Challenge to the Spatial Positioning of Women}

In Mrs. Dalloway, various dimensions of privacy and publicity highlight patriarchal attitudes. Wigley (1992) points out that earlier architecture's premise of safeguarding the genealogical claims of the family by alienating women from other men went parallel with the law of the father propounded by the French psychoanalyst and theorist Jacques Lacan. This constructs the physical house according to patriarchal authority, thereby relating it to generating division. The position of 
architecture, in this context, stands in a place that controls women's sexuality and faithfulness. Similarly, the concept of the private (domestic) space appears historically as a result of articulated aspirations for privacy and comfort, the "consolidation of gendered and familial purposes in life, and domestic practices of consumption and self-representation" (Rice, 2007, p. 1). The Woolfian concept of space, however, contradicts these controversial spatial codes. By strengthening a homogenized view of the house regardless of oppression, conflict, and resistance, Woolf depicts private space in an interrelated and active way against the political representation of domesticity, which is patriarchal, class-tiered, and trying to protect the social structure (Son, 2006). In parallel, Mrs. Dalloway's narrative searches for a sense of stability that is not tied to the domestic sphere; while deliberately disrupting the housewife's understanding of dwelling. Protagonists, including Clarissa, who question the restricted life assigned to them and are eager to escape from it, have been the imaginary pioneers of the feminist uprising, braced through modern fiction. Such protagonists represent the effort, as the political theorist Hannah Arendt suggests, to be at home in the world, although their experiences are fleeting and tentative in modern times (cited in Benhabib, 1996).

\section{Private (Domestic) Space: "The doors would be taken off their hinges."}

Fictional spaces and lives become imaginable through narratives as the reader imagines and locates the characters' experiences within symbolic topographies. In Mrs. Dalloway, Woolf underlines several times that Clarissa Dalloway, like many high-income Londoners, lives in the vicinity of Westminster. For example, when Clarissa leaves the house, she sees her neighbor Scrope Purvis "knowing her as one does know people who live next door to one in Westminster" - (Woolf, 2017 [1925], p. 6), then crosses Victoria Street, and walks towards St. James's Park. Clarissa then thinks:

For having lived in Westminster - how many years now? over twenty, -one feels even in the midst of the traffic, or waking at night, Clarissa was positive, a particular hush, or solemnity; an indescribable pause; a suspense (but that might be her heart, affected, that said, by influenza) before Big Ben strikes. There! Out it boomed (Woolf, 2017 [1925], p. $6)$.

Through cityscape depictions, Woolf enables readers to map the physical environment in which the narrative takes place with an existing location in their mind. According to Johnson (2016), Woolf draws inspiration from her own life while creating her narratives. In this regard, the Dalloways' house bears similarities to Talland House, where Woolf spent her childhood. Talland House's Victorian architectural characteristics such as its French bay windows, wooden floors, staircase, and attic similarly appear in Clarissa's multi-story detached house. Within this regard, although not mentioning any certain architectural characteristics other than the district, street, or city landmark names throughout the narrative, Mrs. Dalloway's living environment appears to consist of the dull stone masonry and urban areas of Westminster, comprising eighteenth- and nineteenth-century Victorian dwellings considering the Talland House and general urban scenery of early twentieth-century London.

Despite not being particularly interested in the discipline of architecture, Woolf shares the same affinity with her modernist architectural contemporaries as she questions the traditionally rigid boundaries of physical space that separate interior and exterior spaces. In the opening scene, 
Clarissa Dalloway's emotions while leaving her 'husband's house' seem especially significant as her reaction is analogous to that of a caged bird that is about to launch into the open air in search of new freedom:

Mrs. Dalloway said she would buy the flowers herself. For Lucy had her work cut out of her. The doors would be taken off their hinges; Rumpelmayer's men were coming. And then, thought Clarissa Dalloway, what a morning - fresh as if issued to children on a beach (Woolf, 2017 [1925], p. 5).

This opening paragraph represents overcoming obstacles to satisfying desires. Clarissa's excitement about the evening's party that will combine her private space with the public is expressed as "the doors would be taken off their hinges" (Woolf, 2017 [1925], p. 5).

Virginia Woolf's fascination with the dichotomy of internal and external time, which is ultimately related to the separation between private and public space, is presented in Mrs. Dalloway. The author's intention of establishing an interplay between private (domestic) and public spaces continues throughout the novel, and these interactions reveal the freedom of feminine consciousness. Hence, Woolf repeatedly employs windows by means of a metaphor and a form of communication to represent the physical and mental relationship between inner and outer spaces, as well as the past and present (Spurr, 2012). In the early pages, Clarissa's windows serve as a 'time machine' that takes the protagonist to her youth in Bourton. Mrs. Dalloway dreams of herself opening the French windows at Bourton:

What a lark! What a plunge! For so it had always seemed to her, when, with a little squeak of the hinges, which she could hear now, she had burst open the French windows and plunged at Bourton into the open air. How fresh, how calm, stiller than this, of course, the air was in the early morning (Woolf, 2017 [1925], p. 5).

Clarissa's imaginary young and free figure standing in front of the window at Bourton's countryside implies a particular domestic position in the narrative. Woolf compares young Clarissa's freedom with 'Mrs.' Dalloway's imprisonment at her own house as the conventional understanding of dwelling is inextricable from an idea of the housewife, one confined within the dwelling's walls. Thus, through Clarissa's imagination, "the door between memory and actuality, inner and outer spaces, is taken off its hinges" (Spurr, 2012, p. 66).

The notion of home is usually represented in relation to family, haven, gender, and journeying (Mallett, 2004). Scholars to examine the relationship of the home with the understanding of gender claim that while men see their dwellings as a symbol of prestige and success, women see them as a shelter (Rainwater, 1966; Madigan, et al., 1990; Somerville, 1997). In Mrs. Dalloway, Woolf's imaginary window as an opening toward the external space connects Clarissa's private (domestic) 'shelter' with the public sphere; it serves as a place for a mixture of the human and non-human dimensions of the narrator's world. Besides, the reader encounters the repeated metaphor of the window as an immaterial agency standing for the opening of feminine desire, which enables the protagonist to observe the world as well as present herself to the social sphere. 
Clarissa's excitement about the upcoming event and party preparations at her house highlight her desire to create her own unique space joining the social and private (domestic) spheres. However, even though all the spaces operate together in the storyline, Clarissa's private and social spheres never merge into one because the physical reality of her life - controlled by society, politics, and the law of the father - can never be reconciled with Clarissa's existential perception of life. As Penner (2000) similarly notes, the protagonist continues to play her gendered roles that are imposed by the patriarchal codes. In parallel, the reader notices that Clarissa's actions in the party, required of her as a high-society lady and the wife of Richard Dalloway, a prominent member of parliament in the conservative government, are nothing but role-playing: "How delightful to see you!' said Clarissa. She said it to everyone. How delightful to see you! She was at her worst - effusive, insincere" (Woolf, 2017 [1925], p. 187).

\section{Public Space: "London; this moment of June."}

Several critics argue that the city or locale is generally sizably important in modern fiction. For example, in the Theory of Literature, Wellek and Warren (1948) mention the contribution of great cities (Paris, London, New York) to the reality of the characters in many modern novels. In this context, cities are not only physical living spaces but also spaces where they represent the narrator's imagination. Novelists may tell a story without stating that they have experienced or witnessed what is being narrated, and write as an omniscient author in the third person. Similarly, Woolf depicts experiences that she collects from the London scene and presents them to her readers in the third person. Such a depiction of a city allows readers to imagine stories happening in real urban topologies. For Woolf, London was a creative inspiration, and as a woman writing in a patriarchal society, she has constantly reshaped the meaning of the city she lived in (Squier, 1985). In Mrs. Dalloway, although the events and characters portrayed by Woolf are imaginary, the spatial portrayal of London and the characters' interaction with the city make the narrative real in the reader's imagination. For example, when Mrs. Dalloway strolls along the streets of London:

In people's eyes, in the swing, tramp, and trudge; in the bellow and the uproar; the carriages, motor cars, omnibuses, vans, sandwich men shuffling and swinging; brass bands; barrel organs; in the triumph and the jingle and the strange high singing of some aeroplane overhead was what she loved; life; London; this moment of June (Woolf, 2017 [1925], p. 43).

According to Bridge and Watson (2003), early feminist writers discussed public spaces of cities as a platform from which feminine consciousness emerges, rather than portraying them as spaces representing patriarchal codes and gendered constraints. Similarly, instead of describing the restrictive aspects of urban life or illustrating these spaces as dangerous places for women, Woolf portrayed London as a space of opportunity and freedom liberated from the boundaries of domestic life. When the reader begins to stroll around in the streets with the protagonist, Woolf first invites the reader to the deepest thoughts of Clarissa, where the protagonist grapples with the feeling of being a woman who is inexistent: "She had the oddest sense of being herself invisible; unseen; unknown; there being no more marrying no more having of children now, but only this astonishing and rather solemn progress with the rest of them" (Woolf, 2017 [1925], p. 13). As a woman, who completed her assigned duties, she and the reader confront the fact that Clarissa being 
a Dalloway does not only mean being Mrs. Dalloway anymore but being "Mrs. Richard Dalloway" (Woolf, 2017 [1925], p. 13). Therefore, she feels the unbearable weight of being married to a prominent male figure that would require her to act in appropriate ways in her social circle. In this sense, the urban space serves as a mechanism to set the protagonist's inner thoughts free.

In this regard, through Clarissa's mobilization in the city, Woolf manipulates the concept of flanerie to express a female view of the urban sphere to challenge the exclusivity of the male persona in the city of modernity. Flânerie, in the simplest terms, refers to the act of strolling. Traditionally depicted as a male, the flaneur figure represents the act of walking around the industrializing city as an observer of modern life. On the other hand, flâneuse refers to the female equivalent of flaneur. The feminine suggestion of the term flaneur stems from the argument that women experience the public space differently from men in modern cities. According to Wolff (1985), flâneuse figures are generally absent in modern literature. Because in modern cities, public/private divisions are highly gendered and exclude women from public spaces and confine them to the private (domestic) sphere. Clarissa's walks as a flâneuse along London's streets are depicted as a way for her to feel 'liberated' and to participate in constructing early twentieth-century urban space.

As Clarissa goes to Bond Street to buy flowers at Mulberry's, her gestures depict the freedom experienced by a woman living in the modern city. The joyous satisfaction she feels from the stimuli of public space helps to mitigate the dullness of her domestic life. As Wigley (1992, p. 335) argues, the woman outside becomes "sexually mobile", and her sexuality is no more bounded by domestic limitations. Public space also affects the protagonist's 'internal space' by allowing her to think about her past and current life while wandering on London streets. As she walks through the streets, Clarissa and the urban space begin to interact with each other. While walking along Bond Street, for example, Mrs. Dalloway's eyes mimic the tracking and panning of a recording. The narrative becomes a record of images and thoughts (Donald, 1997) that project Clarissa's multiple selves past, current, and imaginary - through the depicted metropolis:

Bond Street fascinated her; Bond Street early in the morning in the season; its flags flying; its shops; no splash; no glitter; one roll of tweed in the shop where her father had bought his suits for fifty years; a few pearls; salmon on an iceblock (Woolf, 2017 [1925], p. 13).

The distinction between private and public life becomes more apparent for Clarissa as soon as she returns home after her visit to Bond Street. Her reaction is depicted, not as a relief, but as that of someone entering the space of restriction, the restriction of life:

The hall of the house was cool as a vault. [...] She felt like a nun who has left the world and feels fold round her the familiar veils and the response to old devotions. The cook whistled in the kitchen. She heard the click of the typewriter. It was her life [...] (Woolf, 2017 [1925], p. 33).

Clarissa's perception of her own home is depicted as a gloomy refuge outside another world. In other words, although Dalloways' house is located in London, the protagonist's view of a home is depicted as divergent from the other spaces of the city. Clarissa's domestic life built around "routines, hierarchy, and silence" highlights the gap between the routinized domestic interior and the masculine space of the London streets (Rosner, 2005, p. 149). 


\section{Internal Space: "There was an emptiness about the heart of life; an attic room."}

For men, the home signified status and achievement in the early twentieth century whereas women perceived it as a haven (Madigan et al., 1990). Establishing a comfortable, clean, aesthetically attractive home and maintaining a family life was considered the work attributed to women. Therefore, there was a limited opportunity for women who lived a private life in the domestic sphere to gain political, social, or economic status. In addition, although domesticity refers to a private sphere, domesticity in families emphasized the importance of being together as a family rather than offering personal privacy also for women. As Mallet (2004, p. 75) puts it, “despite home being generally considered a 'feminine space' created by women themselves, they often lacked both authority and a space of their own within this realm". In parallel, when Clarissa returns home, she locks herself in 'a room of her own': the attic. She climbs the stairs while "feeling herself suddenly shrivelled, aged, breastless", and reaches the attic "like a nun withdrawing" (Woolf, 2017 [1925], p. 35). Here, the reader takes a look at the protagonist's personality, where her - Clarissa's, not Mrs. Dalloway's as mother and wife - real existence is locked up (Rachman, 1972):

There was an emptiness about the heart of a life; an attic room. Women must put off their rich apparel. At midday they must disrobe. She pierced the pincushion and laid her feathered yellow hat on the bed. The sheets were clean, tight stretched in a broad white band from side to side. Narrower and narrower would her bed be (Woolf, 2017 [1925], p. 36).

Woolf's repetitive depiction of the tightness and narrowness of the attic room is metaphorically connected with the masculine authority that dominates and oppresses society and imposes designated social roles, especially for women. Cixous (1975, p. 877) describes the notion of the 'narrow room' to which women are limited by men: “They (women) have wandered around in circles, confined to the narrow room in which they've been given a deadly brainwashing". On the other hand, Clarissa's act of putting off her rich apparel in the attic room emphasizes her urge to abandon the gendered social roles that have been assigned to 'Mrs. Dalloway'. As Turner (1992, p. 70) puts it, "women have always served as social actors, rehearsing the various roles as defined and imprinted by men". Clarissa's femininity thus becomes a role-play, a performative mask that she wears to pleasure those in need. What the mask covers, however, is not Clarissa's real persona but her troubling absence. The protagonist comes to face her insufficiency as she stands at the doorway to her attic, looking into the interior space: "So the room was an attic; the bed narrow [...] She could see what she lacked. It was not beauty; it was not mind. It was something central" (Woolf, 2017 [1925], p. 36). Despite the protagonist's wealthy and 'social' lifestyle, the reader inescapably confronts Clarissa's deprivation of 'something central' in the attic room. Woolf, again metaphorically, depicts the protagonist's personality as the attic room: an interior without interiority. On entering the room, the reader observes not Clarissa's presence but something absent within her (Stevenson, 2014).

\section{CONCLUSION}

Literary fiction, by its nature, inherently conveys the ideology of authors to the reader. Authors may transfer their views directly to the reader, or they may store them in the minds and acts of 
protagonists as well as the spaces they dwell. In this regard, literary analyses allow scrutinizing textual meaning to unearth hidden ideologies and critiques of authors behind their narratives, and the analysis of spaces depicted is one of the essential tools to reveal the socio-spatial aspects of a specified timeframe that have remained either unresolved or undiscussed. The literary analysis of spatial representations within Mrs. Dalloway, based upon Virginia Woolfs feminist and modernist viewpoint, allows examining the spatial codes that produce the docile identity of the protagonist Clarissa Dalloway while deciphering the social characteristics of the city's private (domestic) and public spheres.

Analyzing Mrs. Dalloway set in early twentieth-century London, this article aimed to ascertain how Virginia Woolf illustrates the connection between spatial practices of the female protagonist and her assigned gender roles. In rethinking the social norms of privacy and publicity, this article discussed that the spatial critique of Woolf on gender inequality disputes traditional perceptions of patriarchal classifications. The three-partite spatial analysis reveals that the author's attempt to seek the rights of women in thinking, having their own identities, 'rooms', names, emotions, and criticizing disparities are manifested as reflections in the private (domestic), public, and 'internal' spaces throughout Mrs. Dalloway. Although not seeming to resist the patriarchal status quo, Woolfian spaces depicted in the novel serve as a template for the ideological alteration of Clarissa Dalloway, breaking the boundary between privacy and publicity, which is no longer rigid; and thus impenetrable. 


\section{Conflict of Interest Statement}

There is no conflict of interest for conducting the research and/or for the preparation of the article.

\section{Financial Statement}

No financial support has been received for conducting the research and/or for the preparation of the article.

\section{Ethical Statement}

All procedures followed in accordance with the ethical standards.

\section{Author Contribution Statement}

\begin{tabular}{|l|l|l|}
\hline A. Idea, Concept & B. Study Design, Methodology & C. Literature Review \\
\hline D. Supervision & E. Material, Resource Supply & F. Data Collection, Processing \\
\hline G. Analyses, Interpretation & H. Writing Text & I. Critical Review \\
\hline
\end{tabular}

AUTHOR 1: A/B/C/E/F/G/H

AUTHOR 2: B/C/D/E/F/G/H 


\section{REFERENCES}

Algweirien, H. (2017). Virginia Woolf's representation of women: A feminist reading of "The Legacy". English Language and Literature Studies, 7(1), 120-125.

Barker, C. (2005). Cultural studies: Theory and practice. London: Sage Publications.

Baydar, G. (2005). Figures of wo/man in contemporary architectural discourse. In H. Heynen \& G. Baydar (Eds.), Negotiating domesticity: Spatial productions of gender in modern architecture (pp. 3046). London: Routledge.

Baydar, G. (2012). Sexualised productions of space. Gender, Place and Culture, 19(6), 699-706. https://doi.org/10.1080/0966369X.2012.675472.

Benhabib, S. (1996). The reluctant modernism of Hannah Arendt. London: Sage Publications.

Berman, M. (1988). All that is solid melts into air: The experience of modernity. New York: Penguin Books.

Bolak, B. (2000). Constructed space in literature as represented in novels. A case study: "The Black Book" by Orban Pamuk [Unpublished master's thesis], Middle East Technical University.

Bridge, G. \& Watson, S. (2003). City imaginaries. In G. Bridge, S. Watson (Eds.) A companion to the city (pp. 6-17). Oxford: Wiley-Blackwell Publishing.

Cixous, H. (1975). The laugh of the Medusa. (H. Kohen, P. Kohen, Trans.) Signs: Journal of Women in Culture and Society, 1(4), 875-893.

Donald, J. (1997). This, here, now: Imagining the modern city. In S. Westwood, J. Williams (Eds.) Imagining cities: Scripts, signs, memory (pp. 181-201). New York: Routledge.

Ergün, Z. (1990). Mrs. Dalloway ya da başkaldırı [Mrs. Dalloway or rebellion]. Argos, 20, 146158.

Giddens, A. (1991). Modernity and self-identity: Self and society in the late modern age. Cambridge: Polity.

Groover, K. (2008). "Taking the Door off the Hinges: Liminal Space in Virginia Woolf's Mrs. Dalloway." The Literary London Journal, 6(1).

Habermas, J. (1990). The philosophical discourse of modernity: Twelve lectures. MIT Press.

Havik, K. (2006). Lived experience, places read: Toward an urban literacy. Architecture \& Literature. Reflections/Imaginations, OASE, (70), 37-49.

Johnson, A. (2016). "The doors would be taken off their hinges": Space, place and architectural absence in Virginia Woolf. English Studies, 97(4), 412-419. doi: 10.1080/0013838X.2016.1138691.

Larsson, L. (2017). Walking Virginia Woolf's London: An investigation in literary geography. London: Palgrave Macmillan.

Madigan, R., Munro, M. \& Smith, S. J. (1990). Gender and the meaning of the home. International 
Journal of Urban and Regional Research, 14(4), 625-647.

Mallett, S. (2004). Understanding home: A critical review of the literature. The Sociological Review, 52(1), 62-89.

Özcan, S. (2015). Tracing literary architecture: Spatial in-betweenness in Virginia Woolf's Between the Acts (1941) [Unpublished master's thesis], Middle East Technical University.

Payne, M. (1978). Beyond gender: The example of "Mrs. Dalloway". College Literature, 5(1), 1-11.

Penner, B. (2000). The construction of identity: Virginia Woolf's city. In I. Borden, J. Rendell (Eds.) InterSections: Architectural histories and critical theories (pp. 269-282). London: Routledge.

Rachman, S. (1972). Clarissa's attic: Virginia Woolf's Mrs. Dalloway reconsidered. Twentieth Century Literature, 18(1), 3-18.

Rainwater, L. (1966). Fear and house-as-haven in the lower class. American Institute of Planners Journal, 32, 23-31.

Rendell, J. (2000). Introduction: Gender, space. In J. Rendell, B. Penner, I. Borden (Eds.) Gender space architecture: An interdisciplinary introduction (pp. 101-111). London: Routledge.

Rice, C. (2007). The emergence of the interior: Architecture, modernity, domesticity. London: Routledge.

Rosner, V. (2005). Modernism and the architecture of private life. New York: Columbia University Press.

Russell, B. (1945). The history of Western philosophy. London: George Allen \& Unwin Ltd.

Smyth, J. (2008). Transcending traditional gender boundaries: Defining gender roles through public and private spheres. Elements, 4(1), 28-34.

Somerville, P. (1997). The social construction of home. Journal of Architectural and Planning Research, 14(3), 226-245.

Son, Y. (2006). Here and now: The politics of social space in D.H. Lawrence and Virginia Woolf. New York: Routledge.

Spain, D. (1992). Gendered spaces. Chapel Hill: University of North Carolina Press.

Spurr, D. (2007). An end to dwelling: Reflections on modern literature and architecture. In A. Eysteinsson, V. Liska, John Benjamins (Eds.). Modernism (pp. 469-486). Amsterdam: Publishing Company.

Spurr, D. (2012). Architecture and modern literature. Ann Arbor: University of Michigan Press.

Squier, S. M. (1985). Virginia Woolf and London: The sexual politics of the city. Chapel Hill: University of North Carolina Press.

Stevenson, C. (2014). Here was one room, there another: The room, authorship, and feminine desire in a room of one's own and Mrs. Dalloway. Pacific Coast Philology, 49(1), 112-132.

Turner, P. A. (1992). Hélène Cixous: A space between-women and (their) language. Lit: Literature Interpretation Theory, 4(1), 69-77.

Uz Sönmez, F. (2007). Mekânın yazınsallığı ve bir Taşkışla deneyimi [The literacy of space and an 
experience of Taşkışla]. Arredamento Journal, 200(5), 53-57.

Wellek, R. \& Warren, A. (1948). Theory of literature. New York: Harcourt, Brace and Company.

Whitworth, M. H. (2005). Virginia Woolf (Authors in context). Oxford: Oxford University Press.

Wigley, M. (1992). Untitled: The housing of gender. In B. Colomina, J. Bloomer (Eds.) Sexuality and space (pp. 327-389). New York: Princeton Architectural Press.

Wilson. J. M. (2001). Virginia Woolf's London: A guide to Bloomsbury and beyond. London: Tauris Parke Paperbacks.

Wolff, J. (1985). The invisible flâneuse: Women and the literature of modernity. Theory, Culture \& Society, 2(3), 37-46. doi: https://doi.org/10.1177/0263276485002003005.

Wood, A. (2003). Walking the web in the lost London of "Mrs. Dalloway". Mosaic: An Interdisciplinary Critical Journal, 36(2), 19-32. Retrieved June 24, 2021, from http://www.jstor.org/stable/44029458.

Woolf, V. (1925). Mrs. Dalloway. Reprint. London: Macmillan Collector's Library, 2017. 


\section{BIOGRAPHIES OF THE AUTHORS}

\section{Begüm Sena Önal}

Received her B.Des in Interior Architecture and Environmental Design from İzmir University of Economics, Faculty of Fine Arts and Design; and M.Sc. in Interior Design from The Polytechnic University of Milan, School of Design. Currently she continues to her Ph.D. in Architecture and works as a Research Assistant at Yaşar University. Major research interests include spatiality and literature; gender and women's studies; and the interdisciplinary discourses in architecture.

\section{Zeynep Tuna Ultav}

Received her B.Arch and M.Arch in Architecture from Middle East Technical University; and Ph.D. in Architecture from Gazi University. Currently she is an Associate Professor and Department Head of Interior Architecture and Environmental Design at Yaşar University, Faculty of Architecture. Major research interests include architecture and fiction; history and theory of interior architecture; interiors and furniture design in Turkey; architecture and ideology-utopia; and tourism architecture. 